\title{
The Legal Relationship of Conscience to Religion: Refusals to Bear Arms
}

Religion and conscience are inherently ineffable concepts; ${ }^{1}$ but to recognize that they are indefinable is not to suggest that the relationship between them cannot or should not be defined. Indeed, in the context of federal statutes granting conscientious objector exemptions to the requirement of military service ${ }^{2}$ and to the required swearing of an oath to bear arms on behalf of the United States, ${ }^{3}$ the legal system has been forced to define this relationship. In treating refusals to bear arms, Congress and the courts have had to decide whether religion is inclusive of conscience or whether conscience is the larger concept, of which religious beliefs are a part.

In constitutional terms, conscientious objection involves two distinct questions: whether the first amendment compels an exemption for conscientious objectors; ${ }^{4}$ and whether Congress may limit the exemption to those with religiously based opposition to the bearing of arms. ${ }^{\mathrm{s}}$ The first question is not dealt with here; it has been treated exhaustively elsewhere ${ }^{6}$ and the most that one can ultimately conclude is that

1 See generally P. Tillich, Dynamics of Farth (1957); United States v. Kauten, 133 F.2d 703, 708 (2d Cir. 1943).

2 Military Selective Service Act of 1967 § 6(j), 50 U.S.C. \& 456(j) (Supp. V, 1965-69): Nothing contained in this title shall be construed to require any person to be subject to combatant training and service in the armed forces of the United States who, by reason of religious training and belief, is conscientiously opposed to participation in war in any form. As used in this subsection, the term "religious training and belief" does not include essentially political, sociological, or philosophical views, or a merely personal moral code.

8 Immigration and Nationality Act of 1952 § 337(a), 8 U.S.C. \& 1448(a) (1964), provides for an exemption to the required swearing of an oath to bear arms for ". . a person who shows by clear and convincing evidence ... that he is opposed to the bearing of arms in the Armed Forces of the United States by reason of religious training and belief ...."

4 This question is essentially whether the free exercise clause requires the recognition and protection of the beliefs upon which the objector's opposition is based through an exemption of the objector from military service or from the oath to bear arms.

5 The question here is essentially one of whether restriction of the exemption to those with religiously based opposition constitutes an impermissible classification or denial of due process in contravention of the fifth amendment. However, it might also pose an establishment-of-religion issue: Does the granting of an exemption on the basis of religious beliefs and the denying of exemption to nonreligious objectors constitute such a benefit to religion as to be an establishment of religion?

- See Giannella, Religious Liberty, Nonestablishment, and Doctrinal Development, Part 1. The Religious Liberty Guarantee, 80 HARv. L. REv. 1381, 1411-16 (1967); Mans- 
the Supreme Court has preferred to construe the statutory language ${ }^{7}$ so as to avoid the first amendment question. ${ }^{8}$ An answer to the second question, involving the propriety of exempting only religious objectors,

field, Conscientious Objection-1964 Term, 1965 ReLIGION \& PUB. ORDER 3; Comment, The Conscientious Objector and the First Amendment: There but for the Grace of God . . . . , 34 U. CHI. L. REv. 79 (1966); Note, Conscientious Objectors: Recent Developments and a New Appraisal, 70 COLUM. L. REv. 1426 (1970).

7 See discussion of United States v. Seeger, 380 U.S. 163 (1965), in text at note 49 infra, and of United States v. Welsh, 398 U.S. 333, (1970), in text at note 96 infra.

8 The authorities generally cited for the proposition that exemption is a matter of legislative grace either treat that proposition in dicta or have been substantially questioned by later cases. In Selective Draft Law Cases, 245 U.S. 366 (1918), the Court stated that "... the very conception of a just government and its duty to the citizen includes the reciprocal obligation of the citizen to render military service in case of need ...." $I d$. at 378. The case involved an attack upon the Selective Draft Act of 1917 by persons who did not claim to be conscientious objectors but, rather, argued that the Act could not be constitutionally applied to them because it exempted certain types of conscientious objectors and ministers of religion. Thus, the decision of the Court, sustaining the application of the Act to the petitioners, did not answer the question whether Congress is bound to grant any exemption, but rather answered the question whether it is permissible for Congress to draft all eligible men who are not members of the exempt group. The 'Court's statement that "we pass without anything but statement the proposition that an establishment of a religion or an interference with the free exercise thereof repugnant to the First Amendment resulted from the exemption clauses of the act . . . because we think its unsoundness is too apparent to require us to do more," id. at 389-90, may support Congress' right to exempt one group and draft others, but it cannot be read as supporting the right of Congress not to grant an exemption to anyone and draft all.

The other authority generally cited to support the legislative-grace proposition is United States v. Macintosh, 283 U.S. 605 (1931). The Court, through Justice Sutherland, rejected as "astonishing" the statement made in Macintosh's brief that it was a fixed principle of the Constitution that a citizen could not be forced to bear arms against his conscientious scruples: "Of course, there is no such principle of the Constitution, fixed or otherwise. The conscientious objector is relieved from the obligation to bear arms in obedience to no constitutional provision, express or implied; but because, and only because, it has accorded with the policy of Congress thus to relieve him." Id. at 623 .

But Justice Sutherland was speaking to a question not before the Court. This point did not escape the dissenters. Chief Justice Hughes, with Justices Brandeis, Holmes, and Stone concurring, pointed out that the question before the Court was not "whether the Congress may in its discretion compel service in the army in time of war or punish the refusal to serve," but whether by the general language relating to the oath of allegiance Congress intended to impose as a requirement for naturalization that an alien promise to bear arms in defense of the country notwithstanding his conscientious scruples. Id. at 627 (dissenting opinion).

Finally, Justice Sutherland's Macintosh statement was certainly undercut when Macintosh was expressly ovcrruled in Girouard v. United States, 328 U.S. 61 (1946). There, the Court, relying on the Hughes dissent in Macintosh, held that the refusal to promise to take up arms did not indicate a lack of attachment to our institutions, nor render a person incapable of taking the oath of allegiance. While Giroutard does not affirmatively create, by overruling Macintosh, a constitutional right to exemption, it certainly does destroy any authority Macintosh may have provided for the proposition that no such right exists. 
requires a definition of the legal status of conscience in relation to religion. ${ }^{\circ}$

This comment will trace the legal system's consideration of this relationship to the present. The thesis presented is that the two most recent judicial decisions in this area, Welsh $v$. United States ${ }^{10}$ and In re Weitzman,11 adopt a view that in the past had only minority recognition. This view construes the legal concept of conscience to include both sincerely held religious beliefs and sincerely held, nonreligious, conscience-based beliefs. This comment will assume that beliefs which are derived from the "compelling voice of conscience" are a fortiori sincerely held. ${ }^{12}$ Thus, the terms "conscientious objector," "conscientiously held," or "conscientiously opposed," will be used to signify a belief, position, or opposition that is both conscience-based and sincerely held.

\section{Past Expressions of the Relationship of CoNSCiENCE to Religion}

\section{A. Pre-1948 Statutory and Case Law}

1. The Experience with the Draft Act of 1917. Since the First Congress considered Madison's proposal to protect, along with religion, "the full and equal rights of conscience,"13 the relationship between

- Many courts have failed to isolate the two separate questions, and thus make statements confusing answers to the first question with answers to the second. For example, both questions were before the Ninth Circuit when the constitutionality of the Selective Service Act of 1948, 62 Stat. 604, which inserted a requirement of a belief in a Supreme Being for conscientious objectors, was challenged by objectors whose opposition to the bearing of arms was based neither on a command from a Supreme Being nor on any then recognized religious belief. In George v. United States, 196 F.2d 445 (9th Cir.), cert. denied, 344 U.S. 843 (1952), the petitioners argued that either their beliefs placed them within the class to whom Congress extended the exemption or the Act contravened the "free exercise" clause. Non-exemption, it was argued, placed a burden on the free exercise of those beliefs which were the basis of their opposition. The Ninth Circuit, relying on the Selective Draft Law Cases and United States v. Macintosh, held that because Congress can grant or withhold the exemptions as in its wisdom it sees fit, it follows that ". . . Congress ... may deny [the exemption] to persons whose opinions the Congress does not class as 'religious' in the ordinary acceptance of the word." Id. at 450. Such reasoning is fallacious: its major premise is based on inconclusive dicta and an overruled case and the conclusion drawn is a non sequitor. It does not follow from the premise "that no exemption is required," that Congress may grant the exemption to any class that it wishes, while denying the exemption to any other class it wishes, on whatever ground it wishes.

10398 U.S. 333 (1970).

11426 F.2d 439 (8th Cir. 1970).

12 See note 115 infra.

131 Annats of Cong. 451 (1789). It is important to note the precise phraseology of Madison's proposed first amendment because the language suggests not the identification or subsumption of conscience under the legal concept of religion, but the independent 
religion and conscience has received the occasional attention of Congress and the legal system. ${ }^{14}$ But this attention was never close or sustained until the 1917 Draft Act forced consideration of this relationship in connection with refusals to bear arms. The Act exempted a member of "any well-organized religious sect or organization ... whose existing creed or principles forbid its members to participate in war in any form and whose religious convictions are against war or participation therein in accordance with the creed or principles of said religious organizations. ..."15 The exemption was thus twice confined. First, exemption was available only to members of religious sects. Second, it extended only to members of historic, pacifist religious sects, even though religious opposition to war is not necessarily synonymous with pacifism. ${ }^{16}$

The administrative difficulties in determining which sects were both religious and traditionally pacifist and the basic unfairness of the pacifist sect limitation were quickly recognized. President Wilson attempted to deal with the problems by executive order, providing that all draftees conscientiously opposed to combatant services, either on religious or nonreligious grounds, be assigned to noncombatant duty. ${ }^{17}$ The Secretary of War rejected the restriction to members of pacifist sects, and ordered that a broader scope of exemption be applied. ${ }^{18}$ Harlan Fiske Stone, writing of his experience in applying these directives, ${ }^{19}$ made clear the relation of conscience to religion implicit in them:

existence of claims of conscience worthy of constitutional protection: "The civil rights of none shall be abridged on account of religious belief or worship, nor shall any national religion be established, nor shall the full and equal rights of conscience be in any manner, or on any pretext, infringed." Id.

14 For a bibliography of the documents illustrating the place of conscience in the American legal and legislative traditions, see L. Schlisser, CoNsciEnce IN AMERICA (1968). The American consideration of conscience did not begin in an intellectual vacuum. The most concise treatment of the concept of conscience in Western thought is $\mathrm{H}$. Chadwick, Some Reflections on Conscience (1969). See also P. Tiltich, The Protestant ERA 136-50 (1948); Freeman, A Remonstrance for Conscience, 106 U. PA. L. REv. 806 (1958).

15 Selective Draft Act of 1917, 40 Stat. 78.

16 For criticism of the second characteristic, see Rabin, When Is a Religious Belief Religious: United States v. Seeger and the Scope of Free Exercise, 51 CoRNelI L.Q. 231, 233 (1966).

17 Exec. Order No. 2823 (Mar. 20, 1918).

18 U.S. Dep't of War, Statement Concerning the Treatment of Conscientious ObJECTORS IN THE ARMY (1919). The Secretary of War directed that until further instructions on the subject were issued, "personal scruples against war" would be considered as constituting "conscientious objection" and that such persons would be treated in the same manner as other "conscientious objectors . . . ." Id. at 39.

19 Stone was one of the three members of a War Department Board of Inquiry that traveled to army posts, interviewed in-service objectors, and granted exemptions to 
While conscience is commonly associated with religious convictions, all experience teaches us that the supreme moral imperative which sometimes actuates men to choose one course of action in preference to another and to adhere to it at all costs may be disassociated from what is commonly recognized as religious experience. ... [B]oth morals and sound policy require that the state should not violate the conscience of the individual. All our history gives confirmation to the view that liberty of conscience has a moral and social value which makes it worthy of preservation at the hands of the state. So deep in its significance and vital, indeed, is it to the integrity of man's moral and spiritual nature that nothing short of the self-preservation of the state should warrant its violation; and it may well be questioned whether the state which preserves its life by a settled policy of violation of the conscience of the individual will not in fact ultimately lose it by the process. ${ }^{20}$

Stone's statements indicate that the class of exempted persons under the 1917 Act, as administered, included not only those whose opposition to military service was based exclusively on religious beliefs, but also those whose opposition derived from nonreligious, consciencebased beliefs.

2. United States v. Macintosh. ${ }^{21}$ Between the wars, problems of the scope of protected conscience arose in the administration of naturalization law. Perhaps the most significant consideration during this period of the relationship between conscience and religion was the dissent of Chief Justice Hughes in United States v. Macintosh. Macintosh, a Canadian minister and war veteran, refused to take the required oath to bear arms without a proviso that he would participate in war only after first determining the morality of the war and whether it was in conformity with the will of God. The majority affirmed denial of citizenship with this absolutist statement: "We are a Christian people ... whose government must go forward upon the assumption, and safely can proceed upon no other, that unqualified allegiance to Nation and submission and obedience to the laws of the land, as well as those made for war as those made for peace, are not inconsistent with the will of God."22 Hughes' dissent to this position emphasized the "happy tradition" developed by the Court, of "avoiding unnecessary

those whose self-described beliefs placed them within the scope of exemption and who were also found to be sincere in those beliefs.

20 Harlan Fiske Stone, The Conscientious Objector, 21 Cor.um. U.Q. 253, 263, 269 (1919).

21283 U.S. 605 (1931). See more detailed statement of this case, note 8 supra.

22 Id. at 625 . 
clashes with the dictates of conscience." ${ }^{\prime 23}$ The Chief Justice went on to treat protected conscience as a concept inclusive of more than religious beliefs whose favored constitutional status was already clearly established. For example, Hughes stated that " $[t]$ he battle for religious liberty has been fought and won with respect to religious beliefs . . . upon the very ground of the supremacy of conscience."24 As did Stone in administering the 1917 Act, the Macintosh dissenters, joined by Stone who was by then on the Court, considered the class of exempted persons to contain not only those with religiously based opposition, but also those whose opposition derived from nonreligious, "conscientious" sources.

3. The 1940 Selective Service Act and United States v. Kauten. ${ }^{25}$ The Selective Service Act of 1940, when compared to the language of the 1917 Act, appeared ${ }^{26}$ to broaden the scope of the conscientious objector exemption. It provided that: "Nothing contained in this Act shall be construed to require any person to be subject to combatant training ... who, by reason of religious training and belief, is conscientiously opposed to participation in war in any form." 27 Thus, although the 1940 Act did extend the exemption to conscientious objectors who were not members of pacifist religious sects, it did not exempt all those who would have been excused under the 1917 Act as administered. The 1940 Act, with the insertion of "by reason of religious training and belief," rejected the Stone-Hughes suggestion that the scope of protected conscience should extend beyond religious-based conscience. The central test for exemption under the new Act was not whether a person's beliefs were conscience-based, as Stone and Hughes had suggested, but rather whether the beliefs were "religious" 28 within the statute as interpreted by the courts. The courts, however, disagreed as to the proper interpretation.

In United States $v$. Kauten ${ }^{29}$ the Second Circuit interpreted the statutory language expansively (some commentators would say recalcitrantly), ${ }^{30}$ creating a "compelling voice of conscience test." The Second

23 Id. at 634 .

24 Id.

25133 F.2d 703 (2d Cir. 1943).

26 See, e.g., Note, Religious and Conscientious Objection, 21 STAN. L. REv. 1734, 1735 (1969).

27 Ch. $720, \S 5(\mathrm{~g}), 54$ Stat. 889.

28 The congressional intent behind the 1940 Act was to restrict the exemption to those with clear religious objection. See Hearings on H.R. 10132 Before the House Comm. on Military Affairs, 76th Cong., 3d Sess. 191, 201-11, 450-59 (1940).

29133 F.2d 703 (2d Cir. 1948).

80 Several commentators state unequivocally that the Second Circuit's opinion was not in accord with the will of Congress. See, e.g., Conklin, Conscientious Objector Pro. 
Circuit did not presume the relationship of conscience to religion to be an equation, as one commentator concludes, ${ }^{31}$ but a relation of logical identity between conscience and religion. That is, while conscience is not religion, certain conscience-based beliefs are sufficiently analogous to religious beliefs as to be entitled to the legal protection granted religious beliefs. ${ }^{32}$ The court affirmed Kauten's conviction for failure to appear for induction because it was "not convinced . . . that the registrant did not report for induction because of a compelling voice of conscience, which [it would] regard as a religious impulse."33 The Second Gircuit later applied the "compelling voice of conscience" test to exempt a nonreligious objector in United States ex rel Phillips v. Downer, ${ }^{34}$ holding that one who objected primarily on ethical and humanitarian grounds was entitled to the exemption. The court pointed out that "if a stricter rule than was announced in the Kauten case is called for, one demanding a belief which cannot be found among philosophers, but only among religious teachers of recognized organizations, then we are substantially or nearly back to the requirement of the Act of $1917 \ldots . . .35$

The Second Circuit's denial of exemption in Kauten, however, indicates one limit on the expanded legal concept of conscience. There was evidence, cited by the Second Circuit, in the report of the hearing commissioner that " $[t]$ here is no doubt that the Registrant is sincerely opposed to war but this belief emanates from personal philosophical conceptions arising out of his nature and temperament, and which is to some extent, political." ${ }^{30}$ The Second Circuit concluded from such

visions: $A$ View in the Light of Torasco v. Watkins, 51 Geo. L.J. 252, 270-74 (1963); Waite, Section 5(g) of the Selective Service Act, As Amended by the Court, 29 MiNN. L. REv. 22, 27-35 (1944).

31 Note, supra note 26 , at 1735 .

32 M. Konvitz, Religious LIBERTY AND CONSCIENGE: A Constitutional INQUiRY 105 (1968), reviewed, Greenawalt, 70 CoLuM. L. REv. 1133 (1970). Konvitz carries the analogy argument to its logical extreme, arguing that there is a "peripheral right" of conscience which should be added to the first amendment. See also Redlich \& Feinberg, Individual Conscience and the Selective Conscientious Objector: The Right Not to Kill, 44 N.Y.U.L. REv. 875, 888 (1969), in which the authors rely not on Kauten but on an analogy to Griswold v. Connecticut, 381 U.S. 479 (1965), in arguing that the right of conscience is sufficiently analogous to the central meaning of the first amendment to warrant protection.

83133 F.2d at 708 (emphasis added).

34135 F.2d 521 (2d Cir. 1943).

35 Id. at 524. See also United States ex rel. Reel v. Badt, I41 F.2d 845 (2d Cir. 1944); United States ex rel. Brandon v. Downer, 139 F.2d 76 (2d Cir. 1944) (dictum). The Second Circuit later recognized that its approach had been rejected elsewhere and called for a definitive interpretation by the Supreme Court. United States ex rel. Reel v. Badt, I52 F.2d 627, 631 (2d Cir. 1945).

36133 F.2d at 707 n.2. 
evidence that there were substantial indications that the registrant's objections were based on "personal predilection or political and social philosophy respecting the folly and futility of war."37 Thus, while the court was willing to expand the legal concept of protected conscience to include more than purely religious beliefs, it excluded objection based on primarily political considerations.

The Ninth Circuit, in Berman v. United States, ${ }^{38}$ rejected the Kauten approach. Rather than focusing on the meaning of the term "conscientiously" to determine whether exemption was warranted, the Ninth Circuit emphasized the concept of "religion." The court defined "religion" as "an individual's belief in his responsibility to an authority higher and beyond any worldly one,"39 and held that

no matter how pure and admirable [appellant's] standard may be, and no matter how devotedly he adheres to it, his philosophy and morals and social policy without the concept of deity cannot be said to be religion in the sense of that term as it is used in the statute. ${ }^{40}$

It has been argued that the Selective Service Act of 1948, which defined religious training and belief as "an individual's belief in a relation to a Supreme Being involving duties superior to those arising from any human relation, but [not including] essentially political, sociological, or philosophical views or a merely personal moral code,"41 resolved the conflict between the Second and Ninth Circuits in favor of the Ninth and that "Congress apparently sought to foreclose the broader Kauten interpretation and to define religion in terms of belief in and duties toward a Supreme Being." 42 It is true that Congress, by inserting its own definition of religion, did remove the precedential value of the Kauten definition of religious belief as a "belief [which]

37 Id. at 708.

38156 F.2d 377 (9th Cir.), cert. denied, 329 U.S. 795 (1946).

39 Id. at 380 . The court's definition was based on Chief Justice Hughes' Macintosh definition of religion as the "belief in a relation to God involving duties superior to those arising from any human relation." 283 U.S. at 633-34 (dissenting opinion). But given the full impact of the Hughes' dissent, and the inference from it that the class of conscientious objectors must include not only religious objectors but also non-religious, conscientious objectors, the use of the Hughes' definition by the Ninth Circuit to restrict the class of exempted persons undermines the purpose for which it was originally intended.

$40156 \mathrm{~F} .2 \mathrm{~d}$ at 381 .

41 Ch. 625, 62 Stat. 613. Part of the definition is drawn from Hughes' dissent in Macintosh, cited in Berman. But again, the use of Hughes' words to restrict the class of conscientious objectors is contrary to his original intent in Macintosh to expand the class.

42 Note, supra note 26 , at 1736 \& $\mathrm{n.21}$. 
arises from a sense of the inadequacy of reason as a means of relating the individual to his fellow-men and to his universe-a sense common to men in the most primitive and in the most highly civilized societies."43 But the significance of Kauten does not rest on its attempt to define religion, an attempt which the Second Circuit itself felt was unnecessary; ${ }^{44}$ the significance of Kauten lies rather in its treatment of conscience as a legal concept. Thus, Kauten is still important for its recognition that the compelling experience of conscience is analogous to the compulsion of a religious belief and that such conscience-based beliefs should have analogous legal protection. The insertion of the Supreme Being concept into the statute's language did not foreclose this significance.

\section{B. The 1948 Selective Service Act and United States v. Seeger ${ }^{45}$}

In Seeger the Supreme Court interpreted the 1948 Act to reverse the legislative and judicial trend $\mathrm{d}^{46}$ of restricting the scope of protected conscience. Seeger came before the Supreme Court as a consolidation of three cases $^{47}$ in which local draft boards had denied conscientious objector status under the 1948 Act because the boards found that the registrants did not claim opposition to war based on belief in a

$43 \quad 133$ F.2d at 708.

44 Id.

46380 U.S. 163 (1965).

40 See, e.g., Etcheverry v. United States, 320 F.2d 873 (9th Cir.), cert. denied, 375 U.S. 930 (1963); Clark v. United States, 236 F.2d 13 (9th Cir.), cert. denied, 352 U.S. 882 (1956); George v. United States, 196 F.2d 445 (9th Cir.), cert. denied, 344 U.S. 843 (1952). The general trend reversed by Seeger excludes, of course, the Second Circuit opinions, which Seeger might be interpreted as having approved.

47 The Ninth Circuit in Peter v. United States, 324 F.2d 173 (1963), focusing on the "religious" criterion imposed by the 1948 Act, had followed its Berman precedent to define religion in terms of belief in a Supreme Being and to affirm the denial of conscientious objector status. In United States v. Jakobson, 325 F.2d 409 (1963), the Second Circuit had recognized a possible conflict between $\S 6(j)$ and the establishment clause, but avoided a constitutional decision by resorting to an expansive definition of religion to include Jakobson's beliefs within the exemption. In United States v. Seeger, 326 F.2d 846 (1964), the Second Circuit, focusing on the "conscientious" vel non quality of petitioner's objection rather than the "religious" criterion imposed by the Act, confronted the constitutional question. It held the section unconstitutional as an impermissible classification under the due process clause of the fifth amendment because the section required that conscientious objectors believe in a supreme Being, thus discriminating against those whose sincere opposition was based upon conscientious grounds other than belief in a Supreme Being. Id. at 854. Relying on Everson v. Bd. of Educ., 330 U.S. 1 (1946), and Torasco v. Watkins, 367 U.S. 488 (1961), both of which were decided on first amendment grounds, and its own decision in Kauten, to reverse the conviction, the court stated that the due process clause prohibits the drawing of a legally consequential line between a person "obeying the dictates of his conscience or the imperatives of an absolute morality," and a person responding to "the will of a supernatural power." 326 F.2d at 851-53. 
Supreme Being. Certiorari was granted to resolve the conflict in decisions between, not surprisingly, the Second and Ninth Circuits. The sincerity of the registrants was not at issue..$^{48}$

The controlling question in Seeger was whether the distinction between sincere opposition based on a religious belief in a Supreme Being, for which the protection of Congress was granted in the form of an exemption, and sincere opposition to war based on beliefs commonly understood to be moral and not characterized by their holders as religious, for which no exemption was granted, was an unconstitutional violation of the establishment or due process clauses. The Supreme Court avoided the constitutional question, preferring to construe the statute as establishing a test of religion which "avoids imputing to Congress an intent to classify different religious beliefs, exempting some and excluding others. . . ."49 "[T] a 'religion to a Supreme Being' is whether a given belief that is sincere and meaningful occupies a place in the life of the possessor parallel to that filled by the orthodox belief in God of one who clearly qualifies for the exemption."50

While the Seeger test did somewhat abruptly end the ongoing trend of restricting the class of conscientious objectors entitled to exemption, it did not reverse the relative positions of religion and conscience established by the 1948 Act. Rather, the Seeger test, by focusing on and expanding the concept of religion instead of the concept of conscience, made it possible for some, but not all, moral objectors, whose beliefs had previously been defined as nonreligious, to move within the exempted class-but only because those beliefs were defined under Seeger as religious..$^{51}$ Seeger did recognize that some beliefs which the

48 United States v. Seeger, 380 U.S. 163, 166-69 (1965).

$49 \mathrm{Id}$. at 176 . This is not to say that Seeger has no constitutional significance, for it is unlikely that the Court would have adopted via strenuous construction such an expansive definition of religion had it not believed that such a definition was constitutionally required to establish that neither the purpose nor the primary effect of the statute was the advancement or the inhibition of religion. Abington School Dist. v. Schempp, 374 U.S. 203, 222 (1963).

50 380 U.S. at 165-66.

51 This point can be made by asking the question: After Seeger, does one who denies holding any religious belief whatsoever, however religion be defined, but who adheres sincerely to some moral principle outside his own self-centered existence, have a right to exemption? One commentator has argued that Seeger made it logically impossible for even an atheistic, nonreligious objector to fall outside the exempted class, for every sincere disbelicver either "adheres to one of the variations on the theme of universal, humanistic Goodness or else his views are such that he cannot qualify ... for the statutory exemption afforded those who are conscientiously opposed to the taking of life, and if he does adhere to such a system of belief he, ipso facto, is not an 'atheist.'" Rabin, supra note 16, at 244. Another commentator points out that under Seeger, if one is conscientiously opposed to the taking of life, he is not in law an atheist, whatever 
holders may characterize as moral and "which are based upon a power or being, or upon faith, to which all else is subordinate or upon which all else is ultimately dependent"62 are "religious" beliefs within the meaning of the statute, no matter what they are to the holders or are in fact. ${ }^{63}$ However, Seeger expressly refused to extend the exemption to objectors whose opposition is based on purely personal moral codes. Thus, after Seeger, conscientious objectors entitled to exemption still had to be "religious" objectors. ${ }^{54}$

Two ideas presently discussed in non-legal ethical contexts provide the basis for a critique of the Seeger test. First, since the test focuses on the position that the belief occupies in the objector's life, it asks an ambiguous question. Assume the orthodox religious objector's opposition to war is founded on his belief, passed down to him through the religious instruction of his parents, that there exists a God who is

he is in fact. Nevins, The Conscientious Objector and the Constitution, 22 N.Y.U. INTRA. L. REv. 252, 258 (1967). While these points are cogent for those moral, "conscientious" objectors whose opposition derives from a moral principle that recognizes the existence of an ultimate concern outside the holder's existence, because such an opposition becomes religious under Seeger, they cannot be made for all moral objectors. Seeger did not hold that all moral opposition to war is religious within the meaning of the statute.

52380 U.S. at 176.

53 The impact of Seeger was widely discussed by the commentators. See Brodie \& Southerland, Conscience, the Constitution, and the Supreme Court: The Riddle of United States v. Seeger, 1966 WIs. L. REv. 306; Mansfield, supra note 6; Rabin, supra note 16; Note, supra note 26.

54 The most perceptive of the many discussions of the "true" meaning of the Seeger test concluded:

What the Court may mean is that the religious character of a belief is determined not by the place it occupies in the life of the believer, but by the place it ought to occupy in his life, considering the fundamental character of the truths that are asserted. The fact that a belief does occupy an important place in an objector's life may be some indication that it is a belief of a sufficiently fundamental character to warrant characterization as a religious belief, but it is the fundamental character of the truths asserted, and the fact that they address themselves to basic questions about the nature of reality and the meaning of human existence, that is the primary reason for characterizing a belief in these truths as religious.

... If this is what the Court meant to say, the test does have a certain "objective" quality to it. In this respect it does not require an inquiry into the extent to which the belief has transformed the objector's life. It requires, instead, attention to whether the questions to which the belief addresses itself are of a certain character; it requires attention to the subject matter of the belief more than the condition of the believer.

Mansfield, stspra note 6, at 10.

If this is the meaning of the Seeger test, the test is to be praised for its rejection of the major proposition urged in the Government's brief. The Government argued that the presence or non-presence of reason in a belief may be used to distinguish between conscientiously held moral beliefs, which are "reasoned" and not entitled to the legal protection of exemption, and religious beliefs entitled to protection which, according to the Government, are not the product of reason. Brief for Petitioner at 13-14. To accept the Government's proposition would be to limit the exemption to those having absolute fundamentalist religious beliefs and to deny exemption to every man who thought about the nature of faith or morality and the nature of war. 
worthy of being obeyed and who forbids killing. That belief may be both the source and the authority for the religious objector's opposition to war. It is the source of his opposition in that it provided the context for his first hearing and understanding of the evil of war; it is the authority for his opposition in that it is the compulsion, logical or otherwise, behind his opposition. But assume an avowedly nonreligious conscientious objector whose parents were deeply religious. The source of his opposition, like the orthodox objector's, be the belief passed down from his parents through their religious instruction. But the authority for this nonreligious objector's opposition to war is his own mature, personal, and nonreligious (perhaps even political) belief that war is folly. The sources are parallel, the authorities diverse. The Seeger test fails to say which, if either, is controlling. ${ }^{55}$ If the establishment of a religious source of the opposition is dispositive, then the class of exempted conscientious objectors will be more inclusive than if a religious authority for the objector's opposition must be established.

This ambiguity is evinced in the conflicting analysis and disposition of the claims of self-described nonreligious, conscientious objectors with early religious backgrounds. In two cases, the first from the selective service context and the second from the naturalization context, the courts presumed that the establishment of the religious source of the alleged nonreligious objector's opposition qualified the petitioners for exemptions under Seeger without even recognizing, let alone distinguishing, the possible construction of Seeger as requiring that one must establish the religious authority for his opposition. In United States $v$. Shacter ${ }^{56}$ the petitioner was an avowed atheist who had been raised as an orthodox Jew. In religious instruction, his mother had taught him that it was wrong to kill. Attempting to apply the Seeger test to Shacter's beliefs, the court held three factors sufficient to qualify the beliefs under the selective service statute: early religious training, his mother's instruction in conscientious objection, and the religious terminology in which Shacter couched his beliefs. Thus, the court focused on the source of, not the authority for, Shacter's opposition, and granted conscientious objector status to an atheist, viewing his belief as religious under Seeger. The Shacter court failed to demonstrate that the petitioner's early religious training played an authority role in his life, which one might argue is demanded by Seeger. Nothing

55 See generally Nowell-Smith, Morality, Religious and Secular, in ChRIsTIAN ETHIcs and Contemporary Philosophy (I. Ramsey ed. 1966), for discussion of the sourceauthority distinction.

66293 F. Supp. 1057 (D. Md. 1968). 
in the court's opinion even suggests that it was aware of the other possible reading of Seeger. The ambiguity is realized in the naturalization context in In re Nomland..$^{57}$ Nomland, like Shacter, was an atheist with an undisputed religious background (Lutheran) as a child. The court summarily concluded that the beliefs from which her opposition derived were religious within the meaning of that term as set out in Seeger.

The other side of the ambiguity inherent in the Seeger test is evinced in the lower court decision of In re Weitzman. ${ }^{68}$ For the district court, the religious background of the nonreligious objector was not significant and the possibility that her objection may have derived from religious sources was not even considered. Rather, the court, quoting the petitioner's nonreligious description of her opposition, engaged in an "authority" inquiry to conclude that the petitioner's objections were not "religious" because Seeger required that the objector recognize "some external force greater than man's relationship to man which occupied a position in [the objector's] life tantamount to a God or a Supreme Being."69 The court held that the petitioner's beliefs were clearly personal and thus did not entitle her to exemption. ${ }^{60}$

The second criticism of Seeger is that the reliance which the test places on the "fundamental character of the truths or realities upon which the petitioner relies" and on "whether the questions to which the belief addressed itself are of a certain character [the character of a fundamental truth]"'61 is misplaced. The presumption upon which this reliance rests is that sincere religious beliefs, as opposed to insincere ones, are always associated with a faith in the ultimate truth, the ultimate reality of one's position. However, it has been cogently argued in nonlegal contexts that a religious belief may be understood as an intention to behave in a certain way together with the entertainment of religious "stories," associated with the intention in the mind of the believer. That the stories are not "true" in any verifiable sense, nor even believed to be true in the sense of being objectively verifiable, in no way compromises the strength of the belief. ${ }^{62}$ Consider, for example,

67 No. 264215 (C.D. Cal., Jan. 30, 1968) (opinion by Ferguson, J.).

58284 F. Supp. 514 (D. Minn. 1968).

$58 \mathrm{Id}$. at 517 .

$60 \mathrm{Yd}$. at $517,518$.

61 Mansfield, supra note 6, at 10.

62 The noted "neo-orthodox" theologian, Karl Barth, in response to the criticism that statements of religious beliefs cannot be verified in the sense that mathematical or scientific statements can be proven, has argued that the essence of faith lies not in its being open to scientific verification, but in the recognition that the man of faith must constantly seek the ultimate truth that just as constantly escapes him. The essence of faith is its search for understanding, not the limited propositional truth of religious 
the nature of a belief in the efficacy of Mass. Any legal test which requires that a belief be associated with a faith in the fundamental certainty of one's position is asking for an assurance which is alien to the nature of religious faith.

Finally, commentators who recognize the inadequacy of the Seeger test attempt to salvage it with proposed clarifications or eloborations which are overly conceptualistic and which create evident problems of administrability. Thus, one suggests that there is a metaphysical belief, a "cosmic warrant," which supplies the link between the conscience-based views and the religious views which are qualified for protection. ${ }^{63}$ Another suggests that if the conscientious objector can establish ". . . a psychological commitment to and a system of moral practices resulting from the belief," he is entitled to the exemption. ${ }^{64}$ A third feels that if the beliefs asserted concern fundamental questions and "a concept of ultimate dependence or subordination" they are "religious" beliefs within the meaning of Seeger. ${ }^{65}$ These suggested clarifications are merely restatements which themselves lack the potential to be applied objectively and consistently. They illustrate the administrative difficulties of the Seeger test's concern with defining the largely indefinable concept of religion, rather than with recognizing the consciencederived status of nonreligious, moral beliefs. ${ }^{66}$

\section{The Present Expressions: Weitzman and Welsh}

In In re Weitzman and United States $v$. Welsh the Eighth Circuit and the Supreme Court accepted the reasoning of Stone, Hughes, and

language. K. BARTH, ANSELM: Fides QuAerens INTELlectum (1930). But cf. A.J. AYER, LANGUAGE, TRUTH AND LOGic 102-20 (1952).

63 Nevins, supra note 51 , at 259.

64 Comment, Defining Religion: Of God, the Constitution and the D.A.R., 32 U. Crr.

L. REV. 583, 552 (1965).

65 Macgill, Selective Conscientious Objection: Divine Will and Legislative Grace, 54 VA. L. REv. 1355, 1366 (1968).

B6 With the enactment of $\S 1(7)$ of the Military Selective Service Act of 1967, 50 U.S.C. \$ 456(j) (Supp. V, 1965-69), Congress struck from the language of the previous Act, and its definition of "religious training and belief," the reference to "an individual's belief in a relation to a Supreme Being involving duties superior to those arising from any human relation." Thus, the statute presently states merely that "the term "religious training and belief' does not include essentially political, sociological, or philosophical views, or a merely personal moral code." Id. The term remains, however, in the naturalization statute. Despite the legislative change in the selective service area, the courts continued to apply the standard established in Seeger. For example, in United States v. Levy, 419 F.2d 360 (8th Gir. 1969), the court said: "We believe that the 1967 Act in eliminating reference to a 'Supreme Being' and retaining the 'religious training and belief' clause has worked no change in the requirements for a conscientious objector classification, and the construction placed upon the 1948 Act in the Seeger case is the applicable standard." Id. at 366 . 
Kauten that the proper focus of the test for exemption is on the "conscientious" quality of the belief, not its religiousness or nonreligiousness, and, therefore, that the class of exempted persons must be wide enough to include those nonreligious believers whose opposition is based upon the compelling voice of conscience. Weitzman and Welsh also have a particular impact on the precise position of morality in relation to religion and conscience, for they imply that all sincere moral beliefs come within the legal concept of protected conscience, and thus entitle their holders to exemption.

\section{A. Weitzman}

Weitzman involved an alien's application for citizenship. The application was denied by the Immigration and Naturalization Service. In the district court, petitioner contended that section 1448(a) of the Immigration Act was unconstitutional because it granted an exemption from the required oath to bear arms only to those who conscientiously objected because of religious training and belief as that term is defined in the statute. ${ }^{67}$ Alternatively, petitioner argued that she qualified for exemption as a "religious person" under the Seeger test. ${ }^{.8}$ The district court rejected both arguments solely on the basis of its finding, in line with the naturalization examiner's decision, that the petitioner's refusal to take the oath to bear arms or to perform noncombatant service was based on a personal code rather than on the requisite religious training and belief. ${ }^{69}$ But the district court made the additional finding that the petitioner's "sincerity is unquestioned" and that "her credibility is almost beyond doubt."70 On appeal, petitioner questioned only that portion of the district court's decision that related to the constitutionality of the statute, expressly agreeing with the district court's finding that she was not a religious person. ${ }^{71}$ With the case in this posture, both parties advised the Eighth Circuit that this case was one of first impression at the appellate level. ${ }^{72}$

In a split decision, the Eighth Circuit reversed, each judge filing a

67 See generally Brief for Appellant, In re Weitzman, 426 F.2d 439 (8th Cir. 1970).

68 Id.

69 In re Weitzman, 284 F. Supp. 514, 515 (D. Minn. 1968).

$70 \mathrm{Id}$. at 516.

71 Brief for Appellant at 3, In re Weitzman, 426 F.2d 439 (8th Gir. 1970). At the trial the petitioner had described her opposition to the bearing of arms:

My pacifism is not based on any religious or cosmological beliefs. I am a pacifist because of a biological push not a theological pull. As a human being, I have an instinctive aversion to killing other human beings. $I$ believe that this instinct is natural and present in all human beings and is necessary for the preservation of our species.

$426 \mathrm{~F} .2 \mathrm{~d}$ at 442 .

72 Id. at 441 . 
separate opinion. For Judge (now Justice) Blackmun, dissenting, the question presented on appeal was controlled by the petitioner's express acquiescence in the lower court's finding that she was not a religious person. This stance, Blackmun believed, precluded application or further extension of the Seeger parallelism test. ${ }^{73}$ Thus, the issue for Blackmun was narrow and specific: "Is it constitutionally offensive to deny naturalization to an alien solely because her conscientious objection, within the language of the applicable statute, is concededly based on nothing more than 'a merely personal moral code' and arises not at all "by reason of religious training and belief'?"74 Yet Blackmun later added that the "constitutional issue becomes one essentially of classification as between the religious person, however that be defined, and the expressly nonreligious."75 Thus, Blackmun's second statement of the issue appears to conflict with his earlier statement that the Seeger parallelism test is out of the case on appeal. The very function of the Seeger test at the time of Weitzman was to provide the prime, if not only, means of drawing this line of classification between religious and nonreligious persons. If, as Blackmun states, the constitutionality of that line of classification is at issue in Weitzman, then, by implication, Seeger is crucial to the decision. Yet Blackmun, excluding Seeger, concluded simply that since citizenship is a privilege, "although not to be granted or withheld on unconstitutional conditions," 78 and not a constitutional right, the statute may constitutionally draw a line of classification between religious and nonreligious conscientious objectors.

Several points concerning Blackmun's decision should be noted. First, one searches in vain in his opinion for an adequate recognition that what he calls the constitutional issue logically involves two distinct questions-whether any exemption is constitutionally compelled and whether a restrictive classification of the exempted class is constitutional. Moreover, Blackmun indiscriminately cites cases concerning the first question, which was not raised, to support his argument regarding the scope-of-exemption question. Second, Blackmun failed even to discuss Kauten and the Second Circuit's "compelling voice of conscience" test. This is a significant lapse in an opinion which is otherwise remarkable for the range and number of cases cited, discussed, followed or distinguished. Third, and most important, Black-

73 Id. at 444, 448. Judge Blackmun suggested that such a possible expansive reading of the Seeger test as including the petitioner's beliefs of conscience would have been consistent with the decision in United States v. Levy, 419 F.2d 360 (8th Cir. 1969). Id, at 444.

74 Id. at $440-41$.

75 Id. at 448.

$76 \mathrm{Id}$. at 450 . 
mun's analysis and decision accept the 1948 Act's statement on the superior position of religion in relation to conscience, the Act's focus on the meaning of what is "religious" within the term of the statute and not on the meaning of what is "conscientious," and, therefore, the Act's restriction of the class of exempted persons to those with "religious objections." Given these three points, it would indeed have been remarkable had Judge Blackmun "[a]s a member of an inferior federal court ... . even in this permissive day" 77 held for the petitioner.

Judge Heaney felt that the constitutional issue had to be reached:

In my view then, we must either construe the statute as permitting all who sincerely object in conscience to bearing arms to be excused from the oath or hold that the statute is unconstitutional. I take the former course. ${ }^{78}$

The extent to which the Seeger test is involved in and extended by the Weitzman decision is manifest in Heaney's opinion. Indeed, Seeger forms the premise for Heaney's explicit recognition of the legal and constitutional status of conscience:

Seeger and subsequent cases have in all but word given constitutional and statutory dignity to conscience. It is time we do so in fact. To take this step is not to relegate religious belief, to diminish its importance or to show hostility to it. The step additionally recognizes that "to protect religion fully it is necessary to protect conscience." 79

And finally, Heaney, citing Stone's statement as to the independence of conscience from religious experience, ${ }^{80}$ recognized that " $[t]$ he idea that nonreligious conscience deserves protection is not a new one."81

Judge Lay rejected the petitioner's attempt to force the constitutional issue by withdrawing her argument that she was religious under Seeger. Lay argued that "[t]here should be little question that Mrs. Weitzman is a sincere pacifist, and in my judgment, qualifies as being one who reaches this belief on 'religious' grounds."82 Lay's conclusion clarifies the legal relationship of conscience to religion:

77 Id. at 454 .

78 Id. at 460 .

78 Id. at 460-61, quoting M. Konvrtz, supra note 32, at 104 .

80 See text at note 20 supra.

81426 F.2d at 461 .

82 Id. at 457 . As a child, Mrs. Weitzman had received considerable religious instruction. Thus Judge Lay's language might suggest that for him the Seeger test is passed by a nonreligious objector where it is reasonably possible that the source of such objector's opposition was the religious training that he received, while the authority for his objection is a "biological," political, or even economic push. See discussion of the sourceauthority ambiguity in the Seeger test in text at notes 55-60 supra. 
Mrs. Weitzman has established her sincere belief as a conscientious objector on the basis of conscience and sincere conviction. This should be enough. To require her to further justify this faith in scientific terms or as one of religious orthodoxy is patently wrong. Under our constitution "religious" belief can mean nothing more. ${ }^{83}$

While Judge Lay attempted to avoid the constitutional issue, his extension of Seeger to Weitzman's conscientious beliefs has important constitutional implications. It is unlikely that the Supreme Court in Seeger would have resorted to strenuous construction and have adopted such a broad definition of religion in the face of statutory language requiring "belief in relation to a Supreme Being," if it had not felt that such a definition was constitutionally required. Similarly, it is unlikely that Judge Lay would have made the above-quoted expansive statements that "Weitzman has established her sincere belief as a conscientious objector on the basis of conscience and sincere conviction" and that "[u]nder our constitution 'religious' belief can mean nothing more," if he did not realize that recognition of the equivalent legal status of the compelling voice of conscience was constitutionally required.

It is always difficult to isolate the "law of the case" when the various judges' perceptions and reasoning are as diverse as in Weitzman. But the opinion of Judge Heaney, and to a lesser extent that of Judge Lay, represent an adoption of the Stone-Hughes-Kauten position on the relationship of conscience to religion, and strongly suggest the constitutional status of the "compelling voice of conscience." Both opinions recognized an independent status for conscience apart from religion, and both judges, in deciding whether the petitioner's belief entitled her to exemption, focused not on whether those beliefs were "religious," but on whether they were "conscientiously" held. Finally, by exempting the petitioner, both judges recognized that the class of conscientious objectors must be broad enough to include not only those whose opposition to war derives from sincerely held religious beliefs, but also those whose opposition is nonreligious, yet is derived from "the compelling voice of conscience."

\section{B. Welsh}

With Welsh $v$. United States ${ }^{84}$ these points became Supreme Court law. Welsh, who had been convicted for refusing to submit to induction, claimed that he was exempted from combat and non-combat 
service because he was "by reason of religious training and belief ... conscientiously opposed to participation in war in any form." 85 The Ninth Circuit, however, found that there was no religious basis for Welsh's conscientious objector claim, and therefore affirmed the conviction. ${ }^{86}$ A majority of the Supreme Court, speaking through Justice Black, found the controlling facts presented by Welsh "strikingly similar to those in Seeger."87 Both Seeger and Welsh were brought up in religious homes and attended church in their childhood, but in neither case did the church teach its members not to engage in war at any time for any reason. Neither Seeger nor Welsh continued his childhood religious ties into young manhood, and neither belonged to any religious group or adhered to the teaching of any organized religion. ${ }^{88}$ The Court noted that " $[t]$ here was never any question about the sincerity and depth of Seeger's convictions as a conscientious objector, and the same is true of Welsh." 89 The Ninth Circuit had noted the government's concession that Welsh's "beliefs are held with the strength of more traditional religious convictions." 90 But in both cases the Selective Service System had concluded that the beliefs of these men were in some sense insufficiently "religious" to qualify them for conscientious objector exemptions under the terms of the statute.91 In both Seeger's and Welsh's self-description of their beliefs there was the taint of a political dimension, as well as a clear moral content," and "Welsh's conscientious objection to war was undeniably based in part on his perception of world politics."93

The majority in Welsh, as did Judge Lay in Weitzman, rejected the petitioner's attempt to frame the constitutional issue by characterizing

85 Id. at 335.

80404 F.2d 1078 (9th Cir. 1968).

87398 U.S. at 335.

88 Id. at 336 .

80 Id. at 337.

90404 F.2d at 1081 .

01398 U.S. at 337.

22 In Welsh the Court quoted from Seeger's letter to his local board:

My decision arises from what I believe to be considerations of validity from the standpoint of the welfare of humanity and the preservation of the democratic values which we in the United States are struggling to maintain. I have concluded that war, from the practical standpoint, is futile and self-defeating, and from the more important moral standpoint, it is unethical.

398 U.S. at 338.

93 Id. at 342 . The Court quoted from a letter that Welsh wrote to his local board:

$I$ can only act according to what $I$ am and what $I$ see. And I see that the military complex wastes both human and material resources, that it fosters disregard for (what I consider a paramount concern) human needs and ends; I see that the means we employ to "defend" our "way of life" profoundly change that way of life. I see that in our failure to recognize the political, social, and economic realities of the world, we, as a nation, fail our responsibility as a nation.

Id. at 342 (emphasis in original). 
his belief as nonreligious: "The Court's statement in Seeger that a registrant's characterization of his own belief as 'religious' should carry great weight ... does not imply that his declaration that his views are nonreligious should be treated similarly."94 Thus, Black phrases the issue before the Court as precisely that which it faced in Seeger: "[the] task is to decide whether the beliefs professed by a registrant are sincerely held and whether they are, in his own scheme of things, religious [citing Seeger]." 95 As in Seeger, the Court again elected to construe the statute broadly rather than to rely on the Constitution:

We certainly do not think that [the statute's] exclusion of those persons with "essentially political, sociological, or philosophical views or a merely personal moral code" should be read to exclude those who hold strong beliefs about our domestic and foreign affairs or even those whose conscientious objection to participation in all wars is founded to a substantial extent upon consideration of public policy. . . .

... On the basis of these beliefs [Welsh's belief that the taking of life is morally wrong] and the conclusion of the Court of Appeals that he held them "with the strength of more traditional religious convictions," . . . we think Welsh was clearly entitled to a conscientious objector exemption. ${ }^{96}$

With regard to the legal relationship of conscience to religion, two points about the majority's opinion should be emphasized. First, Black attempted a feat of the judicial sleight of hand. On the one hand, he expanded the scope of exemption to include Welsh by giving explicit recognition to the compelling voice of conscience. The concluding sentence of Black's opinion suggested for the first time in a Supreme Court majority opinion the logical conclusion to be drawn from the Stone-Hughes-Kauten position and the Lay and Heaney opinions in Weitzman: "that [the conscientious objector] section exempts from military service all those whose consciences, spurred by deeply held moral, ethical, or religious beliefs, would give them no rest or peace if they allowed themselves to become a part of an instrument of war." ${ }^{\text {gr }}$ Thus, the majority virtually eliminated the "religious training and belief" requirement, substituting a compelling voice of conscience test. But Black's repeated analogies to Seeger, and his statement that "under the standards set out here and in Seeger . . . the registrant is a 'religious'

94 Id. at 341 .

95 Id. at 339 , quoting Seeger, 380 U.S. at 185 (emphasis in original).

96 Id. at $342-43$.

97 Id. at 344. 
conscientious objector," 98 obfuscate the role of the legal concept of conscience in the majority opinion.

The second point to be emphasized concerns the possibility of exempting an objector whose beliefs are essentially political. While the majority opinion stated that the statute "should [not] be read to exclude those who hold strong beliefs about our domestic and foreign affairs or even those whose conscientious objection to participation in all wars is founded to substantial extent upon considerations of public policy,"99 it made clear that to qualify under the Seeger and Welsh standards the registrant's "views cannot be 'essentially political, sociological or philosophical." "100 Thus, the Court, like the Second Circuit in Kauten, ${ }^{101}$ was willing to protect a conscientious belief that has a recognizable political dimension, but only if it also has substantial religious or moral dimensions.

Whereas the majority in Welsh reached its conclusions by statutory construction, Justice Harlan reached the same position in his concurring opinion through constitutional analysis. Harlan asked whether the statute "in limiting this draft exemption to those opposed to war in general because of theistic beliefs runs afoul of the religious clauses of the First Amendment."102 For Harlan, this issue was a resurrection of the debate between the Second and Ninth Gircuits in Kauten and Berman. ${ }^{103}$ In the course of his opinion, Harlan cogently restated the constitutional question in terms relevant to the relationship of conscience to religion: "... whether a statute that defers to the individual's conscience only when his views emanate from adherence to theistic religious beliefs is within the power of Congress."104 If the class of conscientious objectors is limited to only "religious" objectors, and if the statute prohibits the exemption from being extended to nonreligious objectors whose beliefs are based on the compelling voice of conscience, then the statute suffers from "unconstitutional underinclusion."105 Harlan suggested, therefore, that the conscientious objector exemption should have been framed not in religious but in secular, ethical and

$98 I d$. at 343 .

$99 \mathrm{Id}$, at 342 .

$100 \mathrm{Id}$. at 343

101 See text at note 37 supra.

102398 U.S. at 345 . Justice Harlan believes that the constitutional issue must be reached because the liberties taken with the statute in Seeger and Welsh "cannot be justified in the name of ... construing federal statutes in a manner that will avoid possible constitutional infirmities in them." Id. at 345. See Mansfield, supra note 6, at 6. 103398 U.S. at 348-50. See text at notes 25-44 supra.

104398 U.S. at 356.

105 Id. at 361, 364 n.16. 
moral terms. ${ }^{108}$ Yet he concurred in the Court's conscientious objector test, "not as a reflection of congressional statutory intent but as patchwork of judicial making that cures the defect of underinclusion in [the statute] and can be administered by local boards in the usual course of business." 107

Finally, Harlan emphasized the significance of Welsh for the legal relationship of conscience to religion:

Today the [Court] makes explicit its total elimination of the statutorily required religious content for a conscientious objector exemption. The [Court] now says: "If an individual deeply and sincerely holds beliefs that are purely ethical or moral in source and content but that nevertheless impose on him a duty of conscience to refrain from participating in any war at any time (emphasis added)," he qualifies for.... exemption. ${ }^{108}$

\section{Critique of the Post-Welsh Test}

\section{Judicial $^{109}$ and administrative ${ }^{110}$ decisions since Welsh have estab-}

$108 \mathrm{Id}$. at 357.

$107 \mathrm{Id}$. at $366-67$.

$108 \mathrm{Id}$. at 345. In Welsh, Justice White dissented and filed an opinion in which Chief Justice Burger and Justice Stewart joined. Justice Harlan's use of judicial patchwork to cure the statute's constitutional infirmity as an impermissible classification certainly approaches, if indeed it does not reach, what Justice Frankfurter once said the Court must not do:

Certainly this Court cannot be called upon to determine what claims of conscience should be recognized and what should be rejected as satisfying the "religion" which the Constitution protects. That would indeed resurrect the very discriminatory treatment of religion which the Constitution sought forever to forbid.

Bd. of Educ. v. Barnette, 319 U.S. 624, 658 (1943) (Frankfurter, J., dissenting). The majority had decided in this, the second flag salute case, that "the action of the local authorities in compelling the flag salute and pledge transcends constitutional limitations on their power and invades the sphere of intellect and spirit which it is the purpose of the First Amendment to our Constitution to reserve from all official control." Id. at 642. Justice Frankfurter's dissent warrants reading in full because it presents the counterpoint thesis of strict neutrality to limit just how far the "happy tradition" of avoiding clashes with conscience can be carried: "No religion shall either receive the state's support or incur its hostility." Id. at 654. See P. KuRLAND, RELIGION AND the LAw 41-47 (1962).

109 See, e.g., United States v. Rink, 430 F.2d 647 (7th Cir. 1970); United States v. Coffey, 429 F.2d 401 (9th Cir. 1970).

110 Selective Serv. Sys., Local Bd. Memorandum No. 107 (July 6, 1970), purports to establish guidelines that comply with Welsh. In describing those persons still excluded from conscientious objector classification after Welsh, the memorandum states:

Persons whose beliefs are "essentially political, sociological, or philosophical views, or a merely personal moral code" are ineligible to be classified as a conscientious objector. Such persons consist of two groups:

(a) Those with beliefs of religious, moral, and ethical nature, but whose beliefs

are not deeply held, and

(b) Those whose objection to war does not rest at all upon moral, ethical, or 
lished a two-part Welsh test to determine whether a registrant is entitled to a conscientious objector exemption. First, does the petitioner's opposition to war derive from the compelling voice of conscience, or is it merely an opposition which "does not rest at all upon moral, ethical, or religious principle but instead rests solely upon considerations of policy, pragmatism, or expediency?"111 Second, if the opposition is based on conscience-derived beliefs, are those beliefs sincerely held? Although the first inquiry is an accurate derivative of Welsh, the second is questionable, for the petitioner's sincerity was not at issue in Welsh.

\section{A. Comparison of the Welsh and Seeger Tests}

The Welsh test avoids one aspect of conceptualism that was inherent in Seeger-the non-administrable distinction between a sincerely held moral belief and a sincerely held religious belief. ${ }^{112}$ Under Welsh, a deeply held moral belief qualifies its holder for exemption if it is not a "merely personal moral code."113 The Seeger test, on the other hand,

religious principles, but instead rests solely upon consideration of policy, pragmatism or expediency.

Id. The preamble and clause (b) of this statement are indeed part of the Welsh decision's language. However, since Welsh's sincerity was not disputed, clause (a) cannot be said to come from the Welsh decision. But even more important, a literal reading of the preamble and clause (a) reveals that a registrant with religious, moral, or ethical beliefs who is found to be insincere in those beliefs becomes, by some unknown operation, a person "whose beliefs are 'essentially political, sociological, or philosophical views, or a merely personal moral code." "Such a transformation is not only logically absurd but certainly is not supported by anything in Welsh. A person with religious, moral, or ethical beliefs who is found to be insincere, is not by the mere fact of insincerity transformed into a person with "essentially political, sociological, or philosophical views." In these respects, the memorandum seems to misconstrue the precise meaning of Welsh.

111398 U.S. at $342-43$.

112 The elimination of the task of having to distinguish moral, conscientious beliefs from religious, conscientious beliefs is certainly sound because of the ease with which a belief which the holder thinks is moral can be described and treated as a religious belief, and vice versa. For example, even an orthodox religious opposition based on a belief in a Supreme Being can be said to be based on a more fundamental belief that that Supreme Being is wholly good and worthy of being obeyed. Such a fundamental religious belief is itself a very large moral belief. See generally Nielsen, God and the Good: Does Morality Need Religion? Theology Today, April 1964, at 47. As noted in text at note 53 supra, the opposition of a nonreligious, moral objector, if that moral belief is directed toward some ultimate concern, is defined to be religious by Tillich and Seeger. Given the reversibility of the characterizations by registrants of their beliefs and that any one belief can be validly described either as religious or moral, it is not desirable to have the courts attempting to distinguish the "really religious" from the "only moral."

113398 U.S. at 342. Given the expansive statement of Justice Black that "all those whose consciences, spurred by deeply held moral . . . beliefs" are exempted, it is difficult to conceive of any sincerely held moral belief which would now be characterized as a "merely personal moral code." Id. Yet the Selective Service System continues to emphasize that persons with merely personal moral codes are excluded. See SErEcrive SERV. SYs., Local Bd. MEMORANDUM No. 107 (July 6, 1970), quoted in part in note 110 supra. 
could exclude even an orthodox religious person from the class of exempted objectors, if either the source or authority of his opposition derived from a purely personal moral code that he held independent of his religious belief. Seeger's distinction between religious and moral beliefs suggests that these two concepts may occupy separate places in the life of the objector and that the parallel-belief test may be used to isolate those actions of the religious man which are compelled by his religious beliefs from those actions which are compelled by his purely personal moral code. Such a conceptualistic distinction could never be objectively and consistently applied.

The Welsh test, on the other hand, recognizes that a man does not, unless schizophrenic, compartmentalize the moments of his life into a religious period, a period of conscience, and a moral period; he is an integrated personality. Seeger's assumption that courts and administrators can isolate the source of a conscientious decision in a man who is both religious and moral is clearly presumptuous. The context shifts, ${ }^{114}$ and religious beliefs are often inseparable from moral beliefs. The Welsh test allows for such a shift; and because it does, this dimension of the test is a step towards the development of an objective and administrable legal test.

\section{B. The Welsh Sincerity Inquiry}

Practical considerations prohibit the legal system from accepting without question the claims of alleged conscientious objectors. Local boards and courts have utilized the sincerity test to determine the credibility of claimants. Yet the test, while serving a potentially useful function, has often been administered in an abusive and inconsistent manner. ${ }^{115}$

Although courts have said otherwise, a sincerity test cannot help but be affected by the trier's opinion as to the truth or falsity of the belief. United States $v$. Ballard ${ }^{116}$ is generally cited for the proposition that the

114 See generally H. Arken, Reason and Conduct: New Bearungs in Moral Philosophy (1962).

115 See Selective SeRv. Sys., Local Bd. Memorandum No. 107 (July 6, 1970), quoted in part note 110 supra, and United States v. Coffey, 429 F.2d 401 (9th Cir. 1970). Both the Memorandum and the case show that the sincerity test is being used as a corollary inquiry which the purported objector must pass after his beliefs and opposition have been determined to be conscience-derived and not solely a matter of policy, pragmatism, or expediency under the initial Welsh inquiry. There is a distinct possibility that an exhaustive inquiry into whether the objector's opposition is conscience-based renders the second inquiry into sincerity logically unnecessary. Every conscience-based belief may be a fortiori sincerely held.

116322 U.S. 78 (1944). This case involved the mail fraud prosecution of the Ballards of the "I Am" movement, who solicited money on the basis of assertions that Guy Ballard was a divine messenger and that the Ballards could cure diseases. 
sincerity with which a belief is held is a proper question for the trier of fact. The Supreme Court held in Ballard that courts should not try to ascertain the truth or falsity of religious claims, but the majority did not rule on whether the defendants' sincerity had properly been put to the jury. Chief Justice Stone, dissenting, argued that a state of mind can be fraudulently misrepresented, and that a jury could examine whether the Ballard's believed that they had had the experiences they asserted. Justice Jackson, also dissenting, argued that judgments of sincerity cannot be divorced from judgments of truth; if a juror thinks that a belief is wildly implausible, he is likely to think also that it is not sincerely held. Justice Jackson added that since people are often skeptical about religious experience, it is hard to say where belief ends and disbelief begins. Justice Jackson's remarks are equally applicable, after Welsh and Weitzman, to nonreligious, conscientious beliefs. ${ }^{117}$

The operation of the sincerity test after Welsh is illustrated in United States $v$. Coffey. ${ }^{118}$ Coffey had been convicted for refusing induction. The Ninth Circuit reversed the conviction because Coffey's statements about his opposition, "[i] $\mathrm{f}$ they were true, ... indicate that Coffey's intensity of belief was such that his beliefs were based on moral principle, [and that] he had made out a prima facie claim to conscientious objector status." 118 Thus, the court based its reversal on the grounds that Coffey had passed the initial inquiry required under Welsh-he established that his beliefs were conscience-derived. The court added, however, as dictum, that "[i]t would of course have been open to the local board to deny Coffey conscientious objector status upon a finding that his statement of beliefs was insincere,"120 and the court set forth two ways in which Coffey might have failed the sincerity test:

First, it might have been determined that Coffey did not in fact believe what he said he did-i.e., that he did not actually believe that man was a Supreme Being or that men have a special duty to preserve life. The local board might have based such a determination, for example, upon prior statements or actions of Coffey inconsistent with his stated beliefs.

117 The problem as it appears in the context of the relationship is presented by the following language from United States v. Forsting, 304 F. Supp. 84 (D.N.D. 1969): '[W] hile the 'truth' of a belief is not open to question, there remains the significant question whether it is 'truly held.' This is the threshold question of sincerity which must be resolved in every case. It is of course a question of fact-a prime consideration to the validity of every claim for exemption as a conscientious objector." Id. at 86.

118429 F.2d 401 (9th Cir. 1970).

$119 \mathrm{Id}$. at 405 .

$120 \mathrm{Id}$. 
Second, the board might have determined that, though Coffey in fact believed what he said he did, his belief was not "deeply held" within the meaning of Welsh . . -i.e., that despite his beliefs he could bring himself to kill in war, or that the penalty for violating his beliefs would have been only a few pinpricks of conscience, as opposed to the stern remorse which the Welsh test requires. ${ }^{121}$

The Ninth Circuit's first point, like the earlier Seeger test, seems to suggest that sincere belief, as opposed to insincere belief, is associated with some fundamental truth about which the holder is certain and unwavering. But, as noted earlier with regard to the Seeger test, ${ }^{122}$ certainty in the truth of one's position is not the sine qua non of faith. Skepticism of the certainty of one's position has been recognized in theological circles, and even in legal circles, as a desired protection against false idolatry, religious or legal. ${ }^{123}$ It may be argued, however, that it is theoretically possible to posit a sincerity test which would enable the trier of fact to evaluate the sincerity or strength of the objector's belief without requiring the trier to find the underlying assumptions of the belief to be "true." For example, such a test would require the trier to examine the registrant's belief that Christ was crucified, but would not necessitate a finding that Christ was, in fact, crucified. Even if this theoretically narrow sincerity test could be consistently and objectively administered, there remains the danger Justice Jackson recognized in Ballard. A mere fact of demeanor, evincing that the registrant is or is not truthful about his holding this belief, and the ultimate fact that the belief is or is not ultimately true, are not irrevocably separated but are rather part of a continuum of facts associated with the petitioner. It is still difficult to see how the trier's judgment of sincerity can be divorced from a judgment of the truth or falsity of the ultimate fact. There are no internal checks in the sincerity test to insure that the trier will limit his inquiry to the demeanor-level facts and not consider the ultimate truth of petitioner's beliefs.

With regard to the Coffey court's second point, the local boards might have great difficulty in objectively and consistently distinguishing between those who would suffer only a "few pinpricks of conscience" if forced to serve and those who would suffer "stern remorse." It is difficult to see how the fact that an objector really "could" force

121 Id. (emphasis in original).

122 See text at notes 54 \& 61-62 supra.

123 See I P. Thlich, Systematic Theology 13, 216 (The University of Chicago Press ed. 1967). See generally P. TILLICH, Dynamics of FaITH (1957); Holmes, The Path of the Law, 10 HaRv. L. Rev. 457 (1897). 
himself to kill in war is relevant to the decision to withhold an exemption which traditionally has been granted to avoid coercing someone to act contrary to his conscience. Yet the local boards, presumably to test the sincerity of the registrant's conscientious beliefs, almost invariably ask a registrant who has stated that he is opposed to killing for any reason what he would do if a loved one were physically attacked in his presence. Similarly, some courts, in deciding the cases of late-maturing claims of in-service objectors, appear to consider the objector's willingness to engage in weapons training after his alleged "conscientious" belief against the taking of life crystallized as significantly probative of insincerity. ${ }^{124}$

This approach assumes that the sincere "conscientious" objector could not even entertain the possibility of acting contrary to the dictates of his conscience. This assumption illustrates the general failure ${ }^{125}$ of the legal system even to consider the proposition raised by eminent philosophical and theological authorities, ${ }^{126}$ that while the compelling voice of conscience does speak "involuntarily and inevitably," 127 the holder of conscientious beliefs can and often does choose to act contrary to his conscience. It would, however, be exceedingly difficult for the legal system to adopt such a proposition, for the legal system traditionally judges subjective mental states by objective evidence. Yet the possibility remains that acts contrary to the dictates of one's conscience prove only mortality, not insincerity.

Moreover, such use of a sincerity test frustrates any gains in administrability that might have been contemplated in the Welsh decision. The Seeger test utilized a sincerity and strength of belief inquiry to differentiate between "religious" opposition and "purely personal moral" opposition. And this inquiry has been criticized herein as not having the potential to be objectively and consistently administered.128 Now the post-Welsh test, as administered in Coffey and by the Selective Service Administration, attempts to use sincerity to distinguish religious

124 See, e.g., Speer v. Hedrick, 419 F.2d 804, 805 (9th Cir. 1969).

125 But see United States v. Nordloff, No. 18,051 (7th Cir., Jan. 5, 1971). The question on appeal was whether the crystallization of conscientious opposition beyond the registrant's control entitled him to a hearing to determine if he qualified for exemption. While reasoning to its holding that the crystallization is beyond the control of the registrant, the court noted that "we can also control, when faced with the moral issue, whether or not to follow the dictates of conscience." Id.

126 See W. James, A Pluralistic Universe 301-30 (Longmans ed. 1928); W. JaAkes, The Wirl to Believe 145-83 (Longmans ed. 1897); I. Kant, The Critique of Practical REASON 311-12 (Longmans ed. 1954). See generally R. KRöNER, KANT's ETHIGAL WELTANschauung (1956); I P. Tillich, Systematic Theology, supra note 123, at 182-86; II id. at $129-31$; III id. at $32-50$.

127 I. KANT, supra note 126, at 311-12.

128 See text at notes 55-66 supra, and Note, supra note 26, at 1746-47. 
and moral opposition from opposition "which rest[s] solely upon considerations of policy, pragmatism, or expediency."129 If sincerity could not be used to distinguish, objectively and consistently, religious from moral objection, it is difficult to see why it could be used effectively to distinguish religious and moral objectors entitled to the exemption from philosophical, sociological, political and "merely personal moral" objectors. ${ }^{130}$ As the Court itself seemed to imply in Welsh, conscience has a public responsibility where public matters are concerned. A "sincerity" test is of little use in deciding which objectors we will attempt to coerce to abdicate their public responsibility, because their opposition is essentially political, philosophical, sociological, and which objectors we will exempt from the attempted coerced abdication of their public responsibilities, because their opposition is religious and moral. ${ }^{131}$

\section{Exploitation by Highly Verbal Registrants}

Finally, the Welsh test, like the Seeger test before it, may be criticized for the advantage it gives to educated and articulate objectors who consciously or unconsciously can dress up their beliefs in statutory or judicial language to minimize the difficulty in obtaining an exemption..$^{132}$

129398 U.S. at 342-43. See Selective SERv. SYs., Local Bd. Memorandum No. 107 (July 6, 1970), quoted in part note 110 supra, and United States v. Coffey, 429 F.2d 401 (9th Gir. 1970).

130398 U.S. at 342 .

131 A recurrent theme in the judicial expression rationalizing the "happy tradition" of avoiding "unnecessary clashes with the dictates of conscience," United States v. Macintosh, 283 U.S. 605, 634 (1931), is the proposition that whatever is associated with the compelling voice of conscience is necessarily good. This theme is nicely summarized by Stone: "All our history gives confirmation to the view that liberty of conscience has a moral and social value which makes it worthy of preservation at the hands of the state." Stone, supra note 20, at 269. It has often been emphasized that one reason for granting the exemption is that conscientious objectors are usually persons of good character and exemplary citizens. See, e.g., Justice Holmes' remarks about the Quakers in United States v. Schwimmer, 279 U.S. 644, 655 (1929) (dissenting opinion). It has even been suggested that exemption may reflect a belief by our society that conscientious objectors perform a useful function by keeping alive the ideal of nonviolence and the belief that war is not inevitable. Mansfield, supra note 6, at 69 . In short, the legal system has treated that conscience worthy of legal protection as being a good conscience. One suspects that the sincerity test could be used to deny exemption to an objector who, although his beliefs qualify under Welsh as conscience-based, is thought by the trier of fact not to possess a "good" conscience, "good" beliefs, or be worthy of an exemption. Such a potential abusive use of sincerity inquiry to disguise an impermissible ground for denying exemption to the objector is another reason for distrusting the emphasis placed on the sincerity test.

132 See generally Ser.ective SeRv. Sys., Locat Bd. MEmorandum No. 107 (July 6, 1970), for evidence of the conceptualistic formulae inherent in the post-Welsh-Weitzman statement of the law on conscientious objection, waiting to be exploited by those sophisticated enough to find the SSLR (SELECTIVE SERvice LAw REPORTER) volume in which the memo- 
The obstacles to less articulate, less educated objectors are graphically illustrated in Gruca $v$. Secretary of the Army, ${ }^{133}$ where Judge Tamm compared Gruca's simplistic, naive description of his beliefs to Seeger's and Welsh's glib, theologically sophisticated descriptions of their beliefs. It is perhaps possible that the legal system's consideration of the relationship of religion to conscience has pursued not only just the words, rather than the experience behind the words, but only the sophisticated words. ${ }^{134}$

randum is reproduced. The dependence on the nuances of language is exhibited by the informal commentaries written in the margins of the SSLR by prospective objectors attempting to fit their opposition within the stated formulae.

The possibility of verbal manipulation makes some consideration of the purported objector's credibility necessary to distinguish articulate but fabricated opposition from sincere but naively expressed opposition. Thus the articulate objector must be wary lest his articulateness and knowledge of draft law language be taken as fabrication. Just as it is generally presumed that allowing one's witness to testify in the literal words of the statute is disastrous trial strategy because it suggests fabrication by the witness, a purported objector's use of articulate words from judicial opinions and agency memoranda could conceivably backfire.

133 No. 23,849 (D.C. Cir., Oct, 23, 1970). The case was a review of a draft board's finding that Gruca was not entitled to be classified as a conscientious objector. His appeal was denied.

134 In Bortree v. Resor, No. 24,607 (D.C. Cir., Mar. 2, 1971), the court recognized the danger inherent in such a misplaced focus. The court reversed and remanded the district court's decision that there was a basis in fact for the Army's disapproval of the in-service petitioner's application for discharge as a conscientious objector. The Military Selective Service Act of 1967, 50 U.S.C. \$§ 451 et seq. (Supp. V, 1965-69), authorizes judicial inquiry into draft classifications "only when there is no basis in fact for the classification assigned to such registrant. Id. at $\S 460(\mathrm{~b})(3)$. The court in Bortree stated:

An inference of insincerity could logically be drawn from the fact that an applicant for conscientious objector status expresses beliefs in a way which clearly indicates that he is not familiar with them. However, many sincere young men use language derived from their reading and from their moral and spiritual advisers to express their beliefs, and in so doing may give the impression that their thoughts are not their own. Because of this phenomenon, Selective Service Boards and the Army must exercise great care if they attempt to draw conclusions from the manner in which an applicant phrases his beliefs.

Bortree v. Resor, supra. 